\title{
Evaluation of antimicrobial activity of plant extracts from Brazilian savanna on cariogenic cocci
}

\author{
Avaliação da atividade antimicrobiana de extratos vegetais da savanna brasileira \\ sobre cocos cariogênicos
}

\author{
Evaluación de la actividad antimicrobiana de extractos vegetales de sabana \\ brasileña sobre cocos cariogénicos \\ Karina Gerhardt BIANCO ${ }^{1}$ \\ Ellen Cristina GAETTI-JARDIM ${ }^{2}$ \\ Fernanda Lourenção BRIGHENTI ${ }^{3}$ \\ Elerson GAETTI-JARDIM JÚNIOR ${ }^{4}$
}

\author{
${ }^{1}$ PhD. Faculdades Integradas Aparício Carvalho (FIMCA) 76811-678 Porto Velho - RO, Brazil \\ ${ }^{2}$ PhD. Department of Oral and Maxillofacial Surgery, School of Dentistry, Federal University of Mato Grosso do Sul (UFMS) \\ 79070-900 Campo Grande - MS, Brazil \\ ${ }^{3}$ PhD Department of Pediatric Clinic, School of Dentistry, São Paulo State University (UNESP) \\ 14801-903 Araraquara, SP, Brazil \\ ${ }^{4}$ PhD. Department of Pathology and Clinical Propedeutics, School of Dentistry, São Paulo State University (UNESP) \\ 16015-050 Araçatuba, SP, Brazil
}

\begin{abstract}
This study evaluated the antimicrobial activity of 138 aqueous extracts of 23 plants from Brazilian savanna on cariogenic cocci. Aqueous extracts were prepared from leaves, stems and barks of the plants. The initial screening of antimicrobial activity was performed by the agar diffusion method. Minimal inhibitory concentration (MIC) and minimal bactericidal concentrations were determined using broth dilution method. Time-kill curve were also determined on cells in suspension. The initial screening of antimicrobial activity evidenced that leaves extracts from M. ilicifolius, P. americana, J. cuspidifolia and bark extracts of $P$. rotundifolia were active on some strains but not all tested microorganisms. Only leaves, bark and stems extracts of $M$. urundeuva and $P$. cattleianum were able to inhibit all tested strains. The inhibitory activities of $M$. urundeuva and $P$. cattleianum were similar. In general, MBCs were four up to thirty two times higher than MICs. Time-kill curve of the extracts from P. cattleianum and M. urundeuva showed that a log reduction of the planktonic bacterial inoculum was achieved within 60 minutes of contact.

Descriptors: Bacteria; Prevention \& Control; Plant Extracts; Dental Caries.
\end{abstract}

\begin{abstract}
Resumo
Este estudo avaliou a atividade antimicrobiana de 138 extratos aquosos de 23 plantas de savana brasileira sobre cocos cariogênicos. Os extratos aquosos foram preparados a partir de folhas, caules e cascas. A análise inicial da atividade antimicrobiana foi realizada pelo método de difusão em ágar. A concentração mínima inibitória (CIM) e a concentração bactericida mínima foram determinadas utilizando métodos de diluição em caldo. A curva temporal de morte microbiana também foi determinada em células em suspensão. A análie inicial da atividade antimicrobiana evidenciou que os extratos de folhas de $M$. ilicifolius, $P$. americana, J. cuspidifolia e extratos de casca de $P$. rotundifolia eram ativos em algumas cepas mas não em todos os microrganismos testados. Somente os extratos de folhas, cascas e caules de $M$. urundeuva e $P$. cattleianum foram capazes de inibir todas as cepas testadas. As atividades inibitórias de M. urundeuva e $P$. cattleianum foram semelhantes. Em geral, os MBCs eram quatro a trinta e duas vezes mais elevados do que os MICs. A curva tempomorte dos extratos de $P$. cattleianum e $M$. urundeuva mostrou que uma redução logarítmica do inóculo bacteriano planctônico foi alcançada dentro de 60 minutos de contato.

Descritores: Bactérias; Prevenção \& Controle; Extratos Vegetais; Cárie Dentária.
\end{abstract}

\section{Resumen}

Este estudio evaluó la actividad antimicrobiana de 138 extractos acuosos de 23 plantas de sabana brasileña sobre cocos cariogénicos. Los extractos acuosos fueran preparados a partir de hojas, tallos y corteza. El cribado inicial de la actividad antimicrobiana se realizó por el método de difusión en disco. Se determinaron la concentración inhibitoria mínima (MIC) y la concentración bactericida mínima usando métodos de dilución en caldo. La curva de tiempo de muerte microbiana también se determinó en células en suspensión. El cribado inicial de la actividad antimicrobiana evidenció que los extractos de hojas de $M$. ilicifolius, $P$. americana, $J$. cuspidifolia y extractos de corteza de $P$. rotundifolia eran activos en algunas cepas pero no en todos los microorganismos probados. Sólo los extractos de hojas, corteza y tallos de $M$. urundeuva y $P$. cattleianum fueron capaces de inhibir todas las cepas ensayadas. Las actividades inhibitorias de $M$. urundeuva y $P$. cattleianum fueron similares. En general, los CBM eran cuatro hasta treinta y dos veces más altos que los CMI. La curva de matanza de los extractos de $P$. cattleianum y $M$. urundeuva mostró que se logró una reducción logarítmica del inóculo bacteriano planctónico en los 60 minutos siguientes al contacto. Descriptores: Bacterias; Prevención \& Control; Extractos Vegetales; Caries Dental.

\section{INTRODUCTION}

In the past 40 years, there was a significant reduction in the prevalence and severity of dental caries ${ }^{1,2}$. However, oral health still constitutes a serious problem, especially in poor rural communities from developing countries, where social inequalities are severe ${ }^{3}$, and urban populations with middle or low-income ${ }^{3-5}$.
Chemical compounds used during treatment of infections associated with dental microbial biofilm in patients unable to maintain oral hygiene present several side effects when used for long periods ${ }^{6,7}$. Thus, natural compounds such as propolis ${ }^{8}$, guajava ${ }^{9}, \operatorname{cacao}^{10}, \operatorname{araça}^{11-13}$, tea and other beverages ${ }^{14-16}$, and copaiba ${ }^{17}$ have arisen as 
new and effective chemical agents against dental caries and other infections associated with oral microbiota.

Natural products are largely used in traditional medicine or in the diet, especially in developing countries $^{12,13,18,19}$ and might represent advantages over synthetic compounds, such as diversity, flexibility, accessibility, affordability and acceptance ${ }^{20}$. In addition, people concerned about the adverse effects of synthetic drugs have created a new commercial niche for oral hygiene $^{20}$.

In Brazil, the biodiversity observed in tropical forests and savannas offers a wide range of pharmacological and therapeutic compounds with intense activity on microbial biofilms and particular pathogens ${ }^{21,22}$. Moreover, some plant extracts also present several desirable biological properties, such as anti-inflammatory activities ${ }^{23}$.

Only a fraction of Brazilian biological diversity has been evaluated as a source of drugs. In addition, the Brazilian popular medicine is largely described, but most of the information contained therein has not been verified by scientific studies ${ }^{24}$ and the transformation of extensive areas of savanna and transitional forests into commercial crops in the Central-Western and North-Western Brazilian borders may condemn several aspects of the traditional medicine and landscapes to extinction due to the destruction of the environment, pressure of commercial agriculture.

Indigenous and rural populations living in the savannas employ plants as analgesic, anti-septic, antiinflammatory and anti-diarrhea medicine ${ }^{25}$ and for treatment of oral infections. Studies to characterize the anticariogenic potential of Brazilian plant extracts may be valuable to improve oral health in population with low income and noncompliant to conventional preventive procedures as well as encourage the preservation of the natural areas of the Brazilian savannah $^{11-13,20,21,26}$.

The aim of this study was to evaluate the antimicrobial properties of aqueous crude extracts obtained from 23 plants from the Brazilian savanna on reference strains of $S$. mutans and S. sobrinus and clinical isolates.

\section{MATERIAL AND MÉTHOD}

\section{o Microrganisms}

The bacteria used in this study were Streptococcus mutans ATCC 35688 and ATCC 25175, Streptococcus sobrinus ATCC 33478, as well as 10 clinical isolates of S. mutans and 5 isolates of $\mathrm{S}$. sobrinus previously cultivated on Mitis Salivarius Bacitracin Sucrose agar and identified through biochemical and morphological tests and stored at 196oC. Bacteria were grown in tryptic soy broth (TSB Difco, USA) supplemented with yeast extract $(0.5 \%)$, and incubated anaerobically $(90 \% \mathrm{~N} 2 / 10 \% \mathrm{CO} 2)$, at $37^{\circ} \mathrm{C}$ for 24 hours.

\section{○ Plant extracts}

Specimens of Anacardium giganteum, A. occidentale, Anadenanthera falcata, Caryocar brasiliense, Cedrela fissilis, Cordia glabrata, Diptychandra aurantiaca, Ficus enormis, Gallepsia integrifolia, Jacaranda cuspidifolia, Maytenus ilicifolia, Myracrodruon urundeuva, Patagonula americana, Piptocarpha rotundifolia, Platypodium elegans, Psidium cattleianum, Roupala brasiliensis, Solidago microglossa, Tabebuia alba, T. impetiginosa, T. ochraceae, Terminalia argentea and Vanillosmopsis arborea cultivated at the São Paulo State University- UNESP, Araçatuba, São Paulo, Brazil, in natural conditions, without addition of chemical compounds such as chemical fertilizers, pesticides and insecticides were used.
For preparation of the extracts, only leaves, stems and barks of plants without visible signs of decomposition, damage or disease were used. Plants were harvested from January 2006 to April 2013. Botanical identification of the plants was obtained and a classified reference voucher specimen was deposited at the Herbarium of Pharmacognosy and Phytotherapy Research Laboratory, São Paulo, Brazil, and at the Collection of Aromatic and Medicinal Plants at the University of Campinas.

Plants were washed three-times in deionized water, allowed to dry in a dark room (initially at room temperature for 30 days and then at $37^{\circ} \mathrm{C}$ for 15 days) and grinded until a thin powder was achieved. In order to extract water-soluble chemical compounds, $25 \mathrm{~g}$ of the leaves were decocted in $125 \mathrm{ml}$ of deionized water for $5 \mathrm{~min}$ at $100^{\circ} \mathrm{C}$, at $55^{\circ} \mathrm{C}$ for an additional $1 \mathrm{~h}$ and at room temperature for 3 days. The extracts were filter-sterilized using a $0.22 \mu \mathrm{m}$ cellulose membrane (Millipore) and the aqueous extracts were allowed to evaporate at $37^{\circ} \mathrm{C}$ and resuspended in deionized water to achieve final concentration of $15 \mathrm{mg} / \mathrm{ml}^{5}$. The extracts were prepared immediately before use to avoid oxidation or were stored at $-40^{\circ} \mathrm{C}$ during 10 days ${ }^{22}$.

- Screening of antimicrobial activity of the extracts using an agar diffusion method

Sterile filter paper discs $(6 \mathrm{~mm})$ were soaked with $20 \mu \mathrm{l}$ of extract, so that each disc was impregnated with $0.3 \mathrm{mg}$ of residue. The discs were dried at $37{ }^{\circ} \mathrm{C}$ overnight to evaporate residual water. The dry discs were applied to the surface of Mueller Hinton agar plates supplemented with $0.5 \%$ Tween-20, and previously inoculated with $10^{8} \mathrm{CFU}$ of the tested bacterial strain. The plates were incubated in candle jars at $37{ }^{\circ} \mathrm{C}$, for $24-48 \mathrm{~h}$. Antibiotic susceptibility discs including ampicillin, amoxicillin, gentamicin, and tetracycline $(10-30 \mu \mathrm{g})$ were used as controls ${ }^{27}$. The experiment was performed in triplicate and the antibacterial activity was detected by the presence of inhibition of microbial growth around discs.

Only extracts of $M$. urundeuva and $P$. cattleianum presented antimicrobial activity on all tested microbial strains and were evaluated to determine minimal inhibitory and minimal bactericidal concentrations, as well time-kill curves.

o Determination of minimal inhibitory concentrations (MICs) and minimal bactericidal concentrations (MBCs)

In the tests to evaluate the MICs and MBCs only Streptococcus mutans ATCC 35688 and ATCC 25175, and S. sobrinus ATCC 33478 were used.

In order to determine MIC and MBC, plant extracts were added to Mueller Hinton broth supplemented with $0.5 \%$ yeast extract containing $10^{5} \mathrm{CFU}$ of the tested bacterial strain and two-fold serial dilutions of plant extracts, ranging from $0.125 \mathrm{mg} / \mathrm{ml}$ to $128 \mathrm{mg} / \mathrm{ml}$. All tubes were incubated in candle jars at $37^{\circ} \mathrm{C}$, for $48 \mathrm{~h}$. MIC was defined as the lowest concentration that was able to inhibit bacterial growth.

After incubation at $37^{\circ} \mathrm{C}$, for $24-48 \mathrm{~h}$., aliquots of 100 $\mu \mathrm{l}$ from broth with no bacterial growth were plated onto tryptic soy agar supplemented with yeast extract and enriched with $5 \%$ horse blood and incubated at $37^{\circ} \mathrm{C}$ for 48 h. MBC was defined as the lowest concentration where no bacterial growth on agar plates was recorded . In all tests, sterile PBS and broth without plant extracts were use as controls.

\section{- Time-kill curve}

Time-kill curves of extracts from $M$. urundeuva and $P$. cattleianum were established for $S$. mutans ATCC 35688 
and ATCC 25175, and S. sobrinus ATCC 33478. Initially, $10^{5} \mathrm{CFU} / \mathrm{ml}$ were inoculated in Mueller Hinton broth supplemented with $0.5 \%$ yeast extract (TSB). The plants extracts were added at a final concentration corresponding to their MBC. A bacterial suspension in PBS was used as control. At different time intervals (10, 20, 30 min, 1-8 h, 12 $\mathrm{h}$, and $24 \mathrm{~h}$ ), $100 \mu \mathrm{L}$ of the samples were removed, and plated on tryptic soy agar supplemented with yeast extract and horse blood. Colonies were counted after incubation in anaerobiosis at $37^{\circ} \mathrm{C}$ for $24 \mathrm{~h}$.

\section{- Statistical analysis}

Statistical significance was determined by analysis of variance (ANOVA) using the software SPSS 11.0 for Windows. Fisher's exact test was applied to contingency tables to compare the extract effectiveness of the extracts on the cells in suspension. $P<0.05$ values were considered statistically significant.

\section{RESULTS}

The results have evidenced that $7.1 \%$ of the tested plant extracts exhibited inhibitory activity on at least 5 clinical strains of $S$. mutans or $S$. sobrinus. The initial screening of antimicrobial activity by agar diffusion test evidenced that the extracts from Anacardium giganteum, A. occidentale, Anadenanthera falcata, Caryocar brasiliense, Cedrela fissilis, Cordia glabrata, Diptychandra aurantiaca, Ficus enormis, Gallepsia integrifolia, Roupala brasiliensis, Solidago microglossa, Tabebuia alba, T. impetiginosa, T. ochraceae, Terminalia argentea, Vanillosmopsis arborea do not have any antimicrobial activity on tested strains.

Extracts of the leaves of $M$. ilicifolia $(66.7 \%), P$. americana (33.3\%), J. cuspidifolia (44.4\%), F. enormis $(27.8 \%)$ and extracts from bark of $P$. rotundifolia (44.4\%) and $P$. elegans $(44.4 \%)$ were active on some strains but not all tested microorganisms. Only extracts of leaves, bark and stems of $M$. urundeuva and $P$. cattleianum were able to inhibit all tested cariogenic cocci, including reference strains.

The inhibitory activities of $M$. urundeuva and $P$. cattleianum were similar (Table 1). In general MBCs were four up to 32 times higher than MICs. Time-kill curve of the aqueous leaves extracts from $P$. cattleianum and $M$. urundeuva showed similar results for all reference strains tested. A logarithmic reduction of the planktonic bacterial inoculum was achieved within $60 \mathrm{~min}$ after the aqueous extracts from $P$. cattleianum and $M$. urundeuva were added, regardless reference strain tested (Figure 1).

Table 1. Antimicrobial activity aqueous extracts against of leaves from M. urundeuva (1) and P. cattleianum (2) on three reference strains of cariogenic cocci

\begin{tabular}{cccc}
\hline \multirow{2}{*}{ Extract } & \multicolumn{3}{c}{ MIC/MBC (mg/ml) } \\
\cline { 2 - 4 } & S. mutans ATCC 35688 & S. mutans ATCC 25175 & S. sobrinus ATCC 33478 \\
\hline 1 & $8 / 32$ & $4 / 32$ & $2 / 64$ \\
2 & $4 / 32$ & $4 / 32$ & $4 / 64$ \\
\hline
\end{tabular}

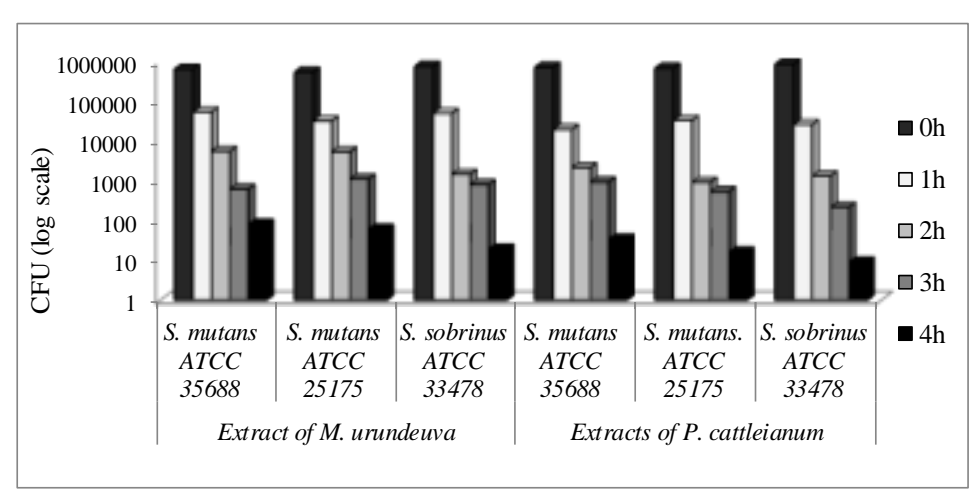

Figure 1: Time-kill curve to cariogenic strains for the alcoholic and aqueous leaves extracts from $M$. urundeuva (A) and P. cattleianum (B).

\section{DISCUSSION}

The control of oral biofilm is fundamental to maintain the balance between host immune defenses and microbial virulence, particularly for human populations living in isolated and poor areas in developing countries, where oral biofilm control is still a serious problem ${ }^{5}$ and efficient therapeutic strategies to completely avoid its formation has not been yet universally established. Brazilian low-income communities use plant extracts to deal with biofilm associated diseases, but most of the natural products have not been scientifically evaluated so far $^{13}$.

Although the use of these products is usually empirical, it is based on the knowledge that plants produce bioactive compounds in response to environmental factors, such as microbial invasion or ultraviolet radiation ${ }^{28,29}$. People living near the margins of the Amazon forest and in the savanna of the Central, North-Eastern, and NorthWestern Brazilian borders, as well other areas of developing world frequently appeal to natural medicines to overcome the lack of public and private medical care. Studies have shown that South America folk medicine provides a wide range of extracts with antimicrobial properties ${ }^{24,30}$, but few studies testing natural extracts as antimicrobials against cariogenic microorganisms are available. The relevance of such issues resides on the ability to provide a fast reduction of microbial adhesion to dental surfaces or microbial viability and these properties are currently under trial to prevent infections associated to dental biofilm, particularly dental caries ${ }^{12,13,16,31}$.

In the present investigation, 138 vegetal extracts were obtained from 23 native species from Brazilian savanna, which is the second largest ecosystem of Brazil. Around 220 species from this biome are reported to be used as traditional medicine, but this number may be underestimated, once less than $1 \%$ of the pharmacological potential savanna's plants have been evaluated ${ }^{32}$. In this study, $7.1 \%$ of the tested extracts evidenced some inhibitory activity, a similar proportion to that verified by Anesini and Peres ${ }^{33}$.

Only two extracts, Myracrodruon urundeuva and Psidium cattleianum, displayed satisfactory activity against all reference strains and clinical isolates. This phenomenon is remarkable, once it is estimated that each plant may represent five to ten structural possibilities of natural products $^{34}$. M. urundeuva has anti-ulcerogenic, analgesic and anti-inflammatory properties ${ }^{35,36}$ and Psidium spp. has been used to treat scurvy, diarrhea, cough, pulmonary diseases and as an anti-inflammatory and hemostatic agent ${ }^{37,38}$ Studies in vitro have evidenced that $P$. cattleianum is capable to reduce microbial viability and adhesion of cariogenic $\operatorname{cocci}^{11}$, reduce the expression of virulence factors $^{20}$ and enamel demineralization by these acidogenic Gram-positive microorganisms ${ }^{21}$.

The mechanism of action $P$. cattleianum may be related to a reduction in the expression of the proteins linked to RNA synthesis, protein synthesis and catabolism, with especial distinction to enzymes required during glycolysis and lactic acid production, as previously evidenced ${ }^{20}$. Although little is known about the composition and mode of action of $M$. urundeuva, data in the literature shows that it has a similar composition to that of $P$. cattleianum $^{39}$, suggesting that both extracts may have a similar mechanism of action.

Since mouthrinses and other chemical products are maintained at inhibitory concentrations in the oral cavity for short periods of time, it is relevant to evaluate the kinetics of 
antimicrobial activity of these extracts, since residues of these compounds might be kept in the oral cavity for sufficient time to interfere with the process of biofilm formation. The time-kill curves to cariogenic strains for aqueous extracts from $M$. urundeuva and $P$. cattleianum evidenced that both extracts were able to reduce $90 \%$ of planktonic microorganisms in less than one hour of contact.

\section{CONCLUSION}

Plant extracts obtained from Brazilian savanna display intense antimicrobial activity against cariogenic cocci and the most active extracts were obtained from $P$. cattleianum and $M$. urundeuva.

\section{ACKNOWLEDGEMENTS}

This study was supported by grants of State of São Paulo Research Foundation (FAPESP - grant 01/09783-0, 03/12763-7 and 2009/52577-4).

\section{REFERENCES}

1. Freire MCM, Reis SCGB, Figueiredo N, Peres KG, Moreira RS, Antunes JLF. Determinantes individuais e contextuais da cárie em crianças brasileiras de 12 anos em 2010. Rev Saúde Pública. 2013; 47(Suppl 3):40-9

2. Veerasamy A, Kirk R, Gage J. Epidemiology of dental caries among adolescents in Tamil Nadu, India. Int Dental J. 2016; 66(3):169-77.

3. Perera I, Ekanayake L. Factors influencing perception of oral health among adolescents in Sri Lanka. Int Dent J. 2008; 58(6):349-55.

4. Robertson PB, Del Aguila M, Anderson MH. Trends in periodontal care. Periodontol 2000. 2002;30:104-10.

5. Iwaki K, Koya-Miyata S, Kohno K, Ushio S, Fukud S. Antimicrobial activity of Polygonum tinctorium Lour: extract against oral pathogenic bacteria. J Nat Med. 2006; 60(2):121-5.

6. Baehni PC, Takeuchi Y. Anti-plaque agents in the prevention of biofilm-associated oral diseases. Oral Dis. 2003; 9(Suppl 1):23-9.

7. Quirynen M, De Soete M, Boschmans G, Pauwels M, Coucke W, Teughels W, et al. Benefit of "on-stage fullmouth disinfection" is explained by disinfection and root planning within 24 hours: a randomized controlled trial. J Clin Periodontol. 2006; 33(9):639-47.

8. Leitão DP, Filho AA, Polizello AC, Bastos JK, Spadaro AC: Comparative evaluation of in-vitro effects of Brazilian green propolis and Baccharis dracunculifolia extracts on cariogenic factors of Streptococcus mutans. Biol Pharm Bull. 2004;27(11):1834-9.

9. Razak FA, Othman RY, Rahim ZH. The effect of Piper betle and Psidium guajava extracts on the cell-surface hydrophobicity of selected early settlers of dental plaque. J Oral Sci. 2006; 48(2):71-5.

10. Matsumoto M, Tsuji M, Okuda J, Sasaki H, Nakano K, Osawa $\mathrm{K}$, et al. Inhibitory effects of cacao bean husk extract on plaque formation in vitro and in vivo. Eur $\mathbf{J}$ Oral Sci. 2004; 112(3):249-52.

11. Brighenti FL, Gaetti-Jardim Jr E, Danelon M, Evangelista GV, Delbem AC. Effect of Psidium cattleianum leaf extract on enamel demineralisation and dental biofilm composition in situ. Arch Oral Biol. 2012;57(8):1034-40.

12. Gaetti-Jardim EC, Gaetti-Jardim Jr E, Schweitzer CM, Okamoto AC. Atividade inibitória do verniz de araçá (Psidium cattleianum Sabine) sobre amostras de
Streptococcus mutans "in vitro". Arch Health Invest 2015;4(6):54-60.

13. Gaetti-Jardim EC, Gaetti-Jardim Jr E, Schweitzer CM, Okamoto AC. Efeitos da aplicação de verniz contendo araçá (Psidium ca ttleianum, Sabine) sobre a microbiota cariogênica e a microdureza de superfície do esmalte de ratos submetidos a desafio cariogênico. Arch Health Invest. 2016; 5(1):43-9.

14. Hamilton-Miller JM. Antimicrobial properties of tea (Camellia sinensis L.). Antimicrob Agents Chemother. 1995; 39(11):2375-7.

15. Gaetti-Jardim Jr E, Landucci LF, Okamoto AC, Akeshigue H. Antimicrobial activity of plants infusions on oral fusobacteria and their adherence to human erythrocytes. Arch Health Invest. 2013; 2(1):3-9.

16. Kawarai T, Narisawa N, Yoneda S, Tsutsumi Y, Ishikawa J, Hoshino $\mathrm{Y}$, Senpuku $\mathrm{H}$. Inhibition of Streptococcus mutans biofilm formation using extracts from Assam tea compared to green tea. Arch Oral Biol. 2016; 68:73-82.

17. Bardají DKR, Silva JJM, Bianchi TC, Eugênio DS, Oliveira PF, Leandro LF, et al. Copaifera reticulata oleoresin: chemical characterization and antibacterial properties against oral pathogens. Anaerobe. 2016; 40:18-27.

18. Tayanin GL, Bratthall D. Black teeth: beauty or caries prevention? Practice and beliefs of the Kammu people. Community Dent Oral Epidemiol. 2006; 34(2):81-6.

19. Yu H-H, Seo S-J, Hur J-M, Lee HS, Lee YE, You YO. Asarum sieboldii extracts attenuate growth, acid production, adhesion, and water-insoluble glucan synthesis of Streptococcus mutans. J Med Food. 2006; 9(4):505-9.

20. Brighenti FL, Luppens SBI, Delbem ACB, Deng DM, Hoogenkamp MA, Gaetti-Jardim Jr E, et al. Effect of Psidium cattleianum leaf extract on Streptococcus mutans viability, protein expression and acid production. Caries Res. 2008; 42(2):148-54.

21. Menezes TEC, Delbem ACB, Brighenti FL, Okamoto AC, Gaetti-Jardim Jr E. Protective efficacy of Psidium cattleianum and Myracrodruon urundeuva aqueous extracts against caries development in rats. Pharm Biol. 2010; 48(3):300-5.

22. Gaetti-Jardim JR E, Landucci LF, Arafat OKK, Ranieri RV, Ramos MMB, Ciesielski FIN, et al. Antimicrobial activity of six plant extracts from the Brazilian savanna on periodontal pathogens. Int J Odontostomat. 2011; 5(3):249-56.

23. Machado AC, Dezan Jr E, Gomes-Filho JE, Cintra LTA, Ruviére DB, Zoccal R, et al. Evaluation of tissue reaction to aroeira (Myracrodruon urundeuva) extracts: a histologic and edemogenic study. J Appl Oral Sci. 2012; 20(4):414-8

24. Lima MR, Souza Luna J, Santos AF, Andrade MC, Sant'Ana AE, Genet JP, et al. Anti-bacterial activity of some Brazilian medicinal plants. J Ethnopharmacol. 2006; 105(1-2):137-47.

25. Monteiro JM, Albuquerque UP, Lins-Neto EM, de Araújo EL, de Amorim EL. Use patterns and knowledge of medicinal species among two rural communities in Brazil's semi-arid northeastern region. J Ethnopharmacol. 2006; 105(1-2):173-86.

26. Violante IMP, Hamerski L, Garcez WS, Batista AL, Chang MR, Pott VJ, et al. Antimicrobial activity of some medicinal plants from the cerrado of the central- 
western region of Brazil. Braz J Microbol. 2012; 43(4):1302-8.

27. Voravuthikunchai S, Lortheeranuwat A, Jeeju W, Sririrak T, Phongpaichit S, Supawita T. Effective medicinal plants against enterohaemorrhagic Escherichia coli O157:H7. J Ethnopharmacol. 2004; 94(1):49-54.

28. Grayer RJ, Harborne JB. A survey of antifungal compounds from higher plants (1982-1993). Phytochemistry. 1994; 37(1):19-42.

29. Martini ND, Katerere DRP, Eloff JN. Biological activity of five antibacterial flavonoids from Combretum erythrophyllum (Combretaceae). J Ethnopharmacol. 2004; 93(2-3):207-12.

30. Sartoratto A, Machado ALM, Delarmelina C, Figueira GM, Duarte MCT, Rehder VLG. Composition and antimicrobial activity of essential oils from aromatic plants used in Brazil. Braz J Microbiol. 2004; 35(4):27580.

31. Kooltheat N, Kamuthachad L, Anthapanya M, Samakchan N, Sranujit RP, Potup P, et al. Kaffir lime leaves extract inhibits biofilm formation by Streptococcus mutans. Nutrition 2016; 32(4):486-90.

32. Felfini MC, Felfini JM. Diversidade alfa e beta no cerrado sensu stricto da chapada pratinha Brasil. Acta Bot Bras 2001;15(2):243-54.

33. Anesini C, Peres C. Screening of plants used in Argentine folk medicine for antimicrobial activity. J Ethnopharmacol. 1993; 39(2):119-28.

34. Maciel MAM, Pinto AC, Veiga Jr VF. Medicinal plants: the need for multidisciplinary scientific studies. Quim Nova. 2002; 25(3):429-38.

35. Rao VS, Viana GSB, Menezes AMS, Gadelha MGT. Studies on the antiulcerogenic activity of Astronium urundeuva Engl. II. Aqueous extract. Braz J Med Biol Res. 1987; 20(6):803-5.

36. Albuquerque UP, Monteiro JM, Ramos MA, de Amorim ELC. Medicinal and magic plants from a public market in northeastern Brazil. J Ethnopharmacol. 2007; 110(1):76-91.

37. Lozoya X, Meckes M, Abou-Zaid M, Tortoriello J, Nozzolillo C, Amason JT. Quercetin glycosides in Psidium guajava Linn. leaves and determination of spasmolytic principle. Arch Med Res. 1994; 25(1):11-5.

38. Jaiarj P, Khoohaswan P, Wongkrajang Y, Peungvicha P, Suriyawong P, Saraya ML, et al. Anticough and antimicrobial activities of Psidium guajava Linn leaf extract. J Ethnopharmacol. 1999; 67(2):203-12.

39. Souza SM, Aquino LC, Milach Jr AC, Bandeira MA, Nobre ME, Viana GS. Antiinflammatory and antiulcer properties of tannins from Myracrodruon urundeuva Allemao (Anacardiaceae) in rodents. Phytother Res. 2007; 21(3):220-5.

\section{CONFLICTS OF INTERESTS}

The authors declare no conflicts of interests.

\section{CORRESPONDING AUTHOR}

Ellen Cristina Gaetti Jardim

ellengaetti@gmail.com

Received 07/12/2016 Accepted 01/01/2017 